\title{
Gene expression profiling in insulinomas of Men1 $\beta$-cell mutant mice reveals early genetic and epigenetic events involved in pancreatic $\beta$-cell tumorigenesis
}

\author{
S Fontanière ${ }^{1,2}, J$ Tost $^{3}$, A Wierinckx $^{5}, J_{\text {Lachuer }}{ }^{5}, J$ Lu $^{1}$, N Hussein $^{1}$, \\ $F_{\text {Busato }}{ }^{3}, I_{\text {Gut }}{ }^{3}, Z-Q$ Wang $^{2,4}$ and C-X Zhang ${ }^{1}$
}

\footnotetext{
${ }^{1}$ Laboratoire Génétique et Cancer, CNRS, UMR5201, Faculté de Médecine, Université Claude Bernard Lyon 1, 69373 Lyon, France

${ }^{2}$ International Agency for Research on Cancer (IARC), 69008 Lyon, France

${ }^{3}$ Centre National de Genotypage, Laboratory for Epigenetics, Cremieux, CP5721, 91057 Evry Cedex, France

${ }^{4}$ Leibniz Institute for Age Research (FLI), Fritz Lipmann Institute e.V., 07745 Jena, Germany

${ }^{5}$ ProfilExpert, Neurobiotec Services, 69676 Bron, France
}

(Requests for offprints should be addressed to C-X Zhang; Email: zhang@sante.univ-lyon1.fr)

\begin{abstract}
Mutations of the MEN1 gene lead to the occurrence of multiple endocrine neoplasia type 1 (MEN1). To gain insights into the mechanisms of the tumorigenesis related to MEN1 inactivation, we have used mice in which the Men1 gene was specifically disrupted in pancreatic $\beta$-cells. In these mice, we observed full penetrance of insulinoma with defined histological characteristics of tumorigenesis. To identify the genetic factors taking part in the tumour development, we performed gene expression profiling analysis of these insulinomas at different stages. Here, we show that in late stage insulinomas, 56 genes are up-regulated and 194 are down-regulated more than fourfold compared with normal pancreatic islets. Clustering analysis reveals the deregulation of Hox gene family and the genes involved in cell proliferation and cell cycle control. The altered expression of Igf2, Igfbp3 and Igfbp6 as well as cyclin A2, B2 and D2 are confirmed by quantitative RT-PCR, with the overexpression of all the three cyclins found in early stage insulinomas. Moreover, an increased proportion of cyclin A2- and D2-expressing cells and the overexpression of insulin-like growth factor 2 (IGF2) protein are detected in mouse Men1 insulinomas by immunostaining. Interestingly, the analysis of DNA methylation patterns by quantitative serial pyrosequencing reveals that four specific CpGs in the intragenic differentially methylated region 2 (DMR2) region of the lgf2 gene known to augment transcription through methylation are significantly hypermethylated in insulinomas of Men1 $\beta$-cell mutant mice at 6 and 10 months of age, even before IGF2 overexpression can be detected. Thus, our data indicate the involvement of both genetic and epigenetic mechanisms in early tumorigenesis of $\beta$-cells related to MEN1 inactivation.
\end{abstract}

Endocrine-Related Cancer (2006) 13 1223-1236

\section{Introduction}

Multiple endocrine neoplasia type 1 (MEN1) is a hereditary syndrome transmitted with an autosomal dominant trait. The disease is characterized by the occurrence of multiple endocrine tumours of the parathyroids, pancreas and anterior pituitary (Thakker 1995, Online Mendelian Inheritance in Man no. 131100). Different laboratories have detected germline mutations of the MEN1 gene in about 70-90\% of familial MEN1 patients (Agarwal et al. 1997, Bassett et al. 1998, Giraud et al. 1998). Somatic mutations were also found in a substantial proportion of several sporadic endocrine tumours, especially in insulinoma, gastrinoma and parathyroid adenoma (Zhuang et al. 1997, Farnebo et al. 1998). The mutations revealed in the above analyses showed a typical 'loss of function' profile, establishing no genotype-phenotype correlation (Wautot et al. 2002). The loss of heterozygosity frequently observed in MEN1 
tumours (Larsson et al. 1988) supports the hypothesis that the MENl gene acts as a tumour suppressor in affected cells.

To generate adequate tools for the study of the mechanisms involved in endocrine malignancy related to MEN1 gene inactivation, we and others have generated Menl mutant mice using either conventional (Crabtree et al. 2001, Biondi et al. 2002, Bertolino et al. 2003b) or conditional gene targeting strategies (Bertolino et al. 2003c, Crabtree et al. 2003, Libutti et al. 2003, Biondi et al. 2004). Heterozygous Men1 mutant mice start to develop the major endocrine tumours seen in MEN1 patients at around 12 months of age, whereas homozygous Menl mutant embryos die at E11.5-E13.5 with multiple developmental defects (Crabtree et al. 2001, Bertolino et al. 2003a). In parallel, pancreatic $\beta$-cell- and parathyroid-specific Menl gene disruption results in the development of insulinoma (Bertolino et al. 2003c, Biondi et al. 2004, Crabtree et al. 2003) and parathyroid adenoma respectively (Libutti et al. 2003). We have noticed that the insulinoma started to appear in $\beta$-cell-specific Men1 mutant mice at around 6 months of age (early stage insulinoma). At 10 months, all the $\beta$-cell-specific Men1 mutant mice developed insulinomas with adenocarcinoma features (late stage insulinoma). Furthermore, mouse Menl insulinomas in this model appeared not only earlier than those found in heterozygous Menl mutant mice, but also relatively synchronized (Bertolino et al. 2003c), making such mice a suitable model for dissecting the genetic events that occur during the tumour initiation and progression. Using this model, we have previously demonstrated the existence of a long interval period between the appearance of menin-inactivated cells and the development of insulinoma. This prompted us to propose the hypothesis that the tumorigenesis of $\beta$-cells triggered by the disruption of the Menl gene needs the participation of other factors (Bertolino et al. 2003c).

To identify these factors, we carried gene expression profiling of the insulinomas developed in $\beta$-cellspecific Menl mutant mice at 6 and 10 months of age, corresponding respectively to the insulinomas at early and late stages (Bertolino et al. 2003c). Our results reveal a substantial number of genes, whose expression is either up- or down-regulated in tumours. More importantly, our data provide evidence that the gene expression profile of the insulin-like growth factor (IGF) and cell cycle pathways is particularly deregulated. Further analysis reveals that the overexpression of IGF2 is accompanied by the hypermethylation of the intragenic DMR2 region containing elements that increase the level of transcription through methylation. Our work highlights the early involvement of both genetic and epigenetic mechanisms in tumorigenesis of $\beta$-cells related to MEN1 inactivation.

\section{Materials and methods \\ $\mathrm{Men1}^{\mathrm{F} / \mathrm{F}_{-}}$RipCre ${ }^{+}$pancreatic $\beta$-cell-specific Men1 mutant mice}

As described previously, pancreatic $\beta$-cell-specific Men1 mutant mice were generated by crossing homozygous mice carrying the floxed allele $\left(M e n 1^{F / F}\right)$ with RipCre transgenic mice expressing the Cre recombinase under the control of the rat insulin promoter, termed $\mathrm{MenI} \mathrm{I}^{\mathrm{F} / \mathrm{F}}$-RipCre ${ }^{+}$mice (Bertolino et al. 2003c). All animal experiments were conducted in accordance with accepted standards of humane animal care and were approved by IARC's Animal Care and Use Committee.

\section{Isolation and culture of mouse pancreatic islets}

Pancreatic islets were isolated from mice of 2-10 months age according to the protocol previously described (Bertolino et al. 2003c). Briefly, $2 \mathrm{ml}$ of $1 \mathrm{mg} / \mathrm{ml}$ collagenase (SERVA, Heidelberg, Germany) in Hank's buffered saline solution was injected into the pancreas through the bile duct. Pancreases were then removed and incubated for $20 \mathrm{~min}$ at $37{ }^{\circ} \mathrm{C}$ and dissociated by mechanical pipetting. Islets were hand-picked from dark field dishes under a dissecting microscopy.

\section{RNA extraction}

Total RNA from the islets were prepared using the RNeasy mini-kit (Qiagen) according to the protocol provided by the manufacturer, including the additional step of DNAse treatment. Total RNA yield was measured using $\mathrm{OD}_{260}$ (optical density), and the quality of isolated total RNA was evaluated with the agilent 2100 bioanalyzer (Agilent Technologies, Palo Alto, CA, USA) for microarray analysis or on a $1 \%$ ethidium bromide stained-gel for quantitative PCR.

\section{Microarray analysis}

\section{RNA amplification}

Total RNA, $2 \mu \mathrm{g}$, was amplified and labelled by a round of in vitro transcription using the message amp aRNA kit (Ambion, TX, USA) following the manufacturer's protocol. Before amplification, all tubes were spiked with synthetic mRNA at different concentrations in order to verify the quality of the 
amplification. aRNA yield was measured with an u.v. spectrophotometer and quality verified on nanochips with the Agilent 2100 bioanalyzer (Agilent Technologies).

\section{Array hybridization and processing}

Biotin labelled aRNA, $10 \mu \mathrm{g}$ was fragmented with $5 \mu \mathrm{l}$ fragmentation buffer in a final volume of $20 \mu 1$. Fragmented aRNA were added to the hybridization solution (GE Healthcare Europe $\mathrm{GmbH}$, Freiburg, Germany) in a final volume of $260 \mu \mathrm{l}$ and injected into the CodeLink Uniset Mouse I Bioarrays containing 10000 mouse genes probes (GE Healthcare). Arrays were hybridized overnight at $37{ }^{\circ} \mathrm{C}$ at $300 \mathrm{rpm}$. The slides were washed in a stringent buffer containing $0.1 \mathrm{M}$ Tris- $\mathrm{HCl} \mathrm{pH} 7.6,0.15 \mathrm{M} \mathrm{NaCl}$ and $0.05 \%$ Tween 20 at $46{ }^{\circ} \mathrm{C}$ for $1 \mathrm{~h}$ followed by a streptavidincy5 (GE Healthcare) detection step. Each slide was incubated in $3.4 \mathrm{ml}$ streptavidin-Cy5 solution for $30 \mathrm{~min}$. After this incubation, the slides were washed four times in $240 \mathrm{ml}$ TNT buffer. For the final washes, the slides were rinsed twice in $240 \mathrm{ml}$ water containing $0.2 \%$ triton. Slides were finally dried by centrifugation at $600 \mathrm{rpm}$.

Slides were scanned using a Genepix 4000B scanner (Axon Instruments, Union City, CA, USA) and Genepix software, with the laser set at $635 \mathrm{~mm}$, laser power at $100 \%$ and photomultiplier tube voltage at $60 \%$. The scanned image files were analyzed using CodeLink expression software, version 4.0 (GE Healthcare), which produces both raw and normalized hybridization signals for each spot on the arrays.

\section{Microarray data analysis}

The overall raw hybridization signal intensity of arrays was normalized using CodeLink expression software version 4.0 (GE Healthcare) by setting the raw hybridization signal on each array as ratio to the median of the array (median intensity is 1 after normalization) for better cross-array hybridization. This study used normalized signal intensities. Probes containing missing data were eliminated from the list. The threshold of detection was calculated using the normalized signal intensity of the 100 negative controls represented in the array. Spots with signal intensity below the threshold were termed 'absent'.

Quality of processing was evaluated by generating scatter plot representations of positive signal distribution. Signal intensities were then transformed by logarithm (based 2). A differential expression of at least 4 (minimal fold change) was retained in order to generate the final list of deregulated genes, whereas the average fold change is used when describing individually the expression level of genes of interest. Statistical comparison and filtering were achieved by using the Genespring software 7.0 (Agilent Technologies).

\section{Quantitative PCR}

Reverse transcription (RT)

Total RNA, 1 or $2 \mu \mathrm{g}$ was reverse transcribed with $0.5 \mu \mathrm{g}$ of oligo(dT) using M-MLV reverse transcriptase (Invitrogen). The absence of contaminating genomic DNA of the RT reactions was controlled by qPCR performed directly on total RNA.

\section{Quantitative PCR}

First-strand cDNA was used for real-time PCR with the Light cycler instrument and FastStart DNA Master SYBR Green I kit (Roche Diagnostics). Primers were designed using Primer3 software (primer3_www.cgi v 0.2 - Whitehead Institute/MIT, USA) and their sequences shown in Supplementary Table 1, which may be viewed online at http://erc.endocrinologyjournals.org/supplemental/. Serially diluted cDNA samples were used to calculate the efficiency of each PCR with RealQuant software (Roche). After an initial Taq activation at $95{ }^{\circ} \mathrm{C}$ for $10 \mathrm{~min}$, Light Cycler PCR was performed using 45 cycles with the following cycling conditions: $95{ }^{\circ} \mathrm{C}$ for $15 \mathrm{~s}, 62{ }^{\circ} \mathrm{C}$ for $5 \mathrm{~s}$ and $72{ }^{\circ} \mathrm{C}$ for $16 \mathrm{~s}$. Directly after the PCR, the machine performed a melting curve analysis by slowly $\left(0.1{ }^{\circ} \mathrm{C} / \mathrm{s}\right)$ increasing the temperature from 68 to $95{ }^{\circ} \mathrm{C}$.

\section{Quantitative PCR analysis}

The level of hypoxanthine guanine phosphoribosyl transferase (HPRT) transcript was used as an internal standard to control the amplification variations due to the differences in the starting mRNA concentrations. The mean of the control samples has been set as 1 , to normalize the results.

\section{Statistical analysis}

Mann-Whitney $U$-test was used to compare means between two groups with $P<0.05$ considered as significant.

\section{Histological and immunohistochemial analysis}

Pancreases were collected from mice, fixed in $4 \%$ buffered formalin for $24 \mathrm{~h}$ and embedded in paraffin. 
Serial sections $(3 \mu \mathrm{m})$ were stained with haematoxylin and eosin (H\&E) or immunostained as described previously (Bertolino et al. 2003c) using the following antibodies: anti-cyclin A recognising mouse cyclin A2 (H-432, 1:200, Santa-Cruz Biotechnology, Santa-Cruz, CA, USA), anti-cyclin D2 (M-20, 1:500, Santa-Cruz Biotechnology), antiIGF-II (1:1000, Monoclonal; Upstate, Charlottesville, VA, USA) and anti-Menin (1:200, Polyclonal; SantaCruz Biotechnology).

\section{Pyrosequencing analysis}

DNA was extracted from five different tissues (endocrine pancreas, exocrine pancreas, adrenal, pituitary and tail). DNA concentration was determined using the Quant-iT dsDNA broad range assay kit (Invitrogen) and normalized to a concentration of $50 \mathrm{ng} / \mu \mathrm{l}$. One microgram DNA was bisulphite converted as described in detail elsewhere (Dupont et al. 2004). Quantitative DNA methylation analysis of the bisulphite-treated DNA was performed by pyrosequencing or, in the case of several sequencing primers, by serial pyrosequencing (Tost et al. 2006). Regions of interest were amplified using $30 \mathrm{ng}$ bisulphite-treated mouse genomic DNA and 5 pmol forward and reverse primers, one of them being biotinylated. Sequences of oligonucleotides for PCR amplification and pyrosequencing are shown in Supplementary Table 2, which may be viewed online at http://erc.endocrinologyjournals.org/supplemental/. The reaction was performed in $1 \times$ HotStar Taq buffer supplemented with $1.6 \mathrm{mM} \mathrm{MgCl} 2,200 \mathrm{mM}$ dNTPs and 2.0 U HotStar Taq polymerase (Qiagen) in a $25 \mu \mathrm{l}$ volume. The PCR program consisted of a $15 \mathrm{~min}$ denaturing step at $95{ }^{\circ} \mathrm{C}$, followed by 50 cycles of $30 \mathrm{~s}$ at $95{ }^{\circ} \mathrm{C}, 30 \mathrm{~s}$ at the respective annealing temperature (Supplementary Table 2, which may be viewed online at http://erc. endocrinology-journals.org/supplemental/) and $20 \mathrm{~s}$ at $72{ }^{\circ} \mathrm{C}$, with a final extension of $5 \mathrm{~min}$ at $72{ }^{\circ} \mathrm{C}$. Amplification products were purified and rendered single-stranded on a Pyrosequencing workstation (Pyrosequencing AB, Uppsala, Sweden) according to the manufacturer's instructions. Quantitative DNA methylation analysis was carried out on a PSQ 96MA system with the PyroGold SQA Reagent Kit (Pyrosequencing) and the results were analyzed using the Q-CpG software (Pyrosequencing). Mann-Whitney $U$-test was used to compare quantitative methylation values between the two groups.

\section{Results}

\section{Gene expression profile of mouse insulinomas developed in Men1 $\beta$-cell-specific mutant mice}

To determine the alteration of gene expression in mouse Menl insulinomas at different stages during tumour initiation and progression, mRNAs were isolated from hand-picked pancreatic islets of two $\mathrm{Menl}^{F / F}$ mice, two Menl $\beta$-cell-specific mutant mice at 6 months and two at 10 months of age. These samples were subject to cDNA array analysis in two independent experiments using CodeLink UniSet Mouse Bioarray (Amersham) that contains 10000 mouse genes, the data from both series of analysis being taken into account for individual gene expression evaluation. Our data revealed a total of 56 overexpressed and 194 repressed genes with more than fourfold minimum fold change in insulinomas from the mutant mice at 10 months compared with the controls (Table 1, Supplementary Table 3, which can be viewed online at http://erc.endocrinology-journals.org/supplemental/). The majority of these genes are involved in signal transduction, transcription, metabolism of protein, cell cycle, metabolism of carbohydrate and cell differentiation (Fig. 1), with the genes from the first group (signal transduction) consisting of $18.4 \%$ of all deregulated genes at 10 months, compared with its distribution (14.2\%) within entire expressed genes (Supplementary Table 4, which may be viewed online at http://erc.endocrinology-journals.org/supplemental/). Among the pancreas-specific transcriptional factors, Pax6 and Foxa2 were up-regulated (1.6- and 2.1-fold respectively) in insulinomas from the mutant mice at 10 months of age when compared with the controls, and Foxal was down-regulated (2.9-fold), while Pax4 and NeuroDl had no change. $P d x l$ and Hlxb9 are not present on our microarray. We also noticed that the expression of several genes involved in carbohydrate and lipid metabolism were deregulated (Fig. 1, Supplementary Table 4, which may be viewed online at http://erc.endocrinology-journals.org/supplemental/), indicating that the molecular basis of glucose and lipid homeostasis in $\beta$-cells is functionally disturbed. Moreover, the altered expression was found with many factors involved in cell cycle control, likely due to the abnormal proliferation of tumour cells. Interestingly, there were only very few genes that altered their expression more than four folds in insulinomas from Menl $\beta$-cell-specific mutant mice at 6 months of age, with three out of ten such genes belonging to the transcription group. We noticed that several genes that are down-regulated are physiologically expressed mainly in islet cell lineages other than $\beta$-cells, such as somatostatin, pancreatic polypeptide and 
Table 1 Partial list of genes with differential expression in 6- and 10-month mouse Men1 insulinomas compared with controls

\begin{tabular}{|c|c|c|c|c|c|}
\hline \multicolumn{6}{|c|}{ Genes differentially expressed between controls and 6 months insulinomas } \\
\hline NM_007495 & Astn1 & Astrotactin & NM_011854 & Oasl2 & $\begin{array}{l}2^{\prime}-5^{\prime} \text { Oligoadenylate synthe- } \\
\text { tase-like } 2\end{array}$ \\
\hline NM_019446 & Barhl1 & BarH-like 1 & NM_009130 & Scg3 & Secretogranin III \\
\hline NM_009945 & Cox7a3 & $\begin{array}{l}\text { Cytochrome c oxidase, subunit } \\
\text { Vlla } 3\end{array}$ & & & \\
\hline \multicolumn{6}{|c|}{ Down-regulated genes } \\
\hline NM_018866 & Scyb13 & $\begin{array}{l}\text { Small inducible cytokine sub- } \\
\text { family } \mathrm{B} \text {, member } 13\end{array}$ & NM_007598 & Cap1 & $\begin{array}{l}\text { Adenylyl cyclase-associated } \\
\text { CAP protein homolog } 1\end{array}$ \\
\hline NM_019812 & Sirt1 & Sirtuin 1 & NM_019395 & Fbp1 & Fructose bisphosphatase 1 \\
\hline \multirow{2}{*}{\multicolumn{6}{|c|}{$\begin{array}{l}\text { Genes differentially expressed between controls and } 6 \text { months insulinomas } \\
\text { Up-regulated genes }\end{array}$}} \\
\hline & & & & & \\
\hline NM_007765 & Crmp1 & $\begin{array}{l}\text { Collapsin response mediator } \\
\text { protein } 1\end{array}$ & NM_019548 & Maged3 & Melanoma antigen, family D, 3 \\
\hline NM_053071 & Cox6c & $\begin{array}{l}\text { Cytochrome c oxidase, subunit } \\
\text { Vic }\end{array}$ & NM_008970 & Pthlh & $\begin{array}{l}\text { Parathyroid hormone-like } \\
\text { peptide }\end{array}$ \\
\hline NM_009945 & Cox7a3 & $\begin{array}{l}\text { Cytochrome c oxidase, subunit } \\
\text { Vlla } 3\end{array}$ & NM_019642 & Rpn2 & Ribophorin II (Rpn2) \\
\hline NM_009920 & Cnil & Cornichon (Drosophila)-like & NM_009065 & Rin & $\begin{array}{l}\text { RAS-like protein expressed in } \\
\text { neuron }\end{array}$ \\
\hline NM_011854 & Oasl2 & $\begin{array}{l}2^{\prime}-5^{\prime} \text { Oligoadenylate synthe- } \\
\text { tase-like } 2\end{array}$ & NM_008858 & Prkcm & Protein kinase $\mathrm{C}, \mathrm{mu}$ \\
\hline NM_007495 & Astn1 & Astrotactin & NM_009130 & Scg3 & Secretogranin III \\
\hline NM_019446 & Barhl1 & BarH-like 1 & NM_007906 & Eef1a2 & $\begin{array}{l}\text { Eukaryotic translation elonga- } \\
\text { tion factor } 1 \text { alpha } 2\end{array}$ \\
\hline NM_007388 & Acp5 & $\begin{array}{l}\text { Acid phosphatase } 5 \text {, tartrate } \\
\text { resistant }\end{array}$ & NM_023612 & Esm1 & $\begin{array}{l}\text { Endothelial cell-specific } \\
\text { molecule } 1\end{array}$ \\
\hline NM_016707 & Bcl11a & B-cell CLL/lymphoma 11A & NM_016917 & Slc39a1 & Solute carrier family 39 \\
\hline \multicolumn{6}{|c|}{ Down-regulated genes } \\
\hline NM_008124 & Gjb1 & $\begin{array}{l}\text { Gap junction membrane } \\
\text { channel protein beta } 1\end{array}$ & NM_022032 & Perp & $\begin{array}{l}\text { p53 Apoptosis effector related to } \\
\text { Pmp22 }\end{array}$ \\
\hline NM_008101 & Gcgr & Glucagon receptor & NM_013639 & Prph1 & Peripherin \\
\hline NM_008006 & Fgf2 & Fibroblast growth factor 2 & NM_009521 & Wnt3 & $\begin{array}{l}\text { Wingless-related MMTV inte- } \\
\text { gration site } 3\end{array}$ \\
\hline NM_007482 & Arg1 & Arginase 1, liver & D83144 & Six3 & mRNA for Six 3a, complete cds \\
\hline NM_010253 & Gal & Galanin & NM_010020 & Slc6a3 & $\begin{array}{l}\text { Solute carrier family } 6 \text {, member } \\
3\end{array}$ \\
\hline NM_008116 & Ggtp & $\begin{array}{l}\text { Gamma-glutamyl transpepti- } \\
\text { dase }\end{array}$ & NM_009215 & Smst & Somatostatin \\
\hline NM_010000 & Cyp2b9 & $\begin{array}{l}\text { Cytochrome } \mathrm{P} 450,2 \mathrm{~b} 9 \text {, pheno- } \\
\text { barbitol inducible, type a }\end{array}$ & NM_008456 & Klk5 & Kallikrein 5 \\
\hline NM_007442 & Alx4 & Aristaless 4 & NM_008918 & Ppy & Pancreatic polypeptide \\
\hline NM_007557 & Bmp7 & Bone morphogenetic protein 7 & NM_011168 & Pripf & Prolactin-like protein $\mathrm{F}$ \\
\hline NM_010810 & Mmp7 & Matrix metalloproteinase 7 & NM_009042 & Reg1 & Regenerating islet-derived 1 \\
\hline NM_007559 & Bmp8b & Bone morphogenetic protein $8 b$ & NM_030553 & Olfr7b & Olfactory receptor $7 b$ \\
\hline NM_011260 & Reg3g & $\begin{array}{l}\text { Regenerating islet-derived } 3 \\
\text { gamma }\end{array}$ & NM_011259 & Reg3a & $\begin{array}{l}\text { Regenerating islet-derived } 3 \\
\text { alpha }\end{array}$ \\
\hline
\end{tabular}

Fold change is $\geq 4$.

vasointestinal peptide. The down-regulation of these genes is thus most likely due to the reduced proportion of these cells in Menl insulinomas.

\section{Clustering analysis highlighting the deregulation of the Hox, IGF and cell cycle pathways}

To gain further insights into the altered gene expression in mouse Menl insulinomas, we performed clustering analysis of the data. Previous studies have reported that menin is required for the regulation of several members of the Hox gene family through its interaction with MLL1/2 protein complex, including Hoxa9 (Yokoyama et al. 2004), Hoxc6 and Hoxc8 (Hughes et al. 2004). Indeed, our analysis showed that among 19 Hox genes with detectable expression levels, 5 were down-regulated (Fig. 2A), including Hoxa3 (4.3-fold), Hoxb3 (3.7-fold), Hoxb5 (2.2-fold), Hoxb13 


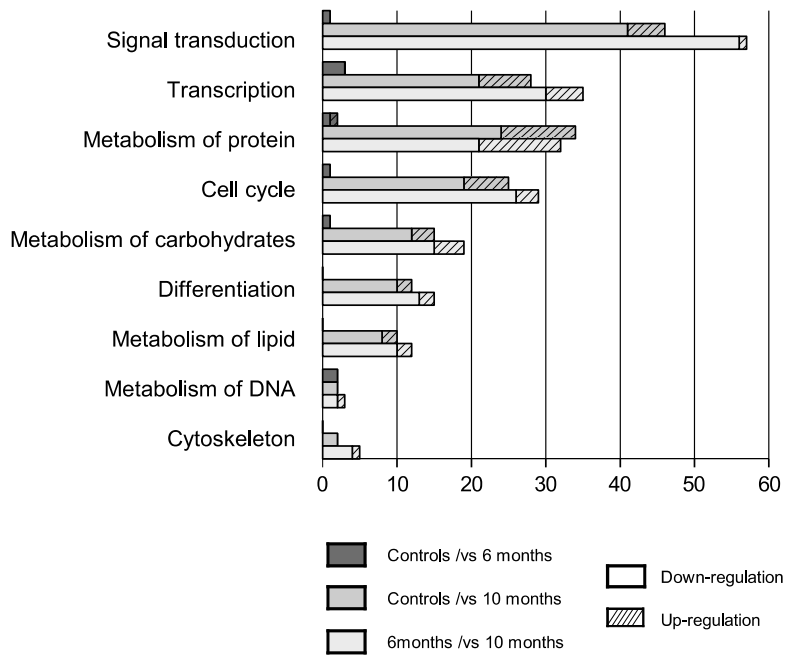

Figure 1 Functional distribution of differentially expressed known genes in control islets versus 6- or 10-month mouse Men1 insulinomas. Gene functions were established based on the annotation provided by the Gene Ontology database. Hatched bars represent genes that are down-regulated compared with controls; solid bars represent genes that are over-expressed compared with controls; The genes having minimal fold change $\geq 4$ are included.

(3-fold) and Hoxcl3 (3-fold) as compared with the control. Hoxa9 and Hoxc8 were not expressed in either insulinoma or control samples, whereas Hoxc6 was unchanged in insulinomas compared with the controls. Our data indicate that menin inactivation in islets affects the expression of other members of the family that are previously not known to be regulated by MLL1/2-menin complexes.

The IGF pathway is known to play an important role in $\beta$-cell proliferation and differentiation, as well as in glucose homeostasis (Vasavada et al. 2006). At 10 months of age, the expression of many members of this pathway is altered in mouse Menl insulinoma (Fig. 2B). Igfl and Igfbp6 are down-regulated more than fivefold, whereas Igfbp 3 and $I g f 2$ are up-regulated 2.1- and 4.5-fold respectively. Several proteins involved in cell cycle control have previously been reported to be important for the control of the islet cell proliferation, especially cyclin D1 (Cozar-Castellano et al. 2004), CDK4 (Rane et al. 1999, Marzo et al. 2004) and p27 (Uchida et al. 2005). Our data showed that cyclin Dl was not detectable in both insulinomas and control samples, p16, p18 and p19 expressed similarly in insulinomas and controls, whereas p27 is not included in our microarray. However, we found that many other genes in this group are subject to altered gene expression (Fig. 2C), particularly the increased expression of cyclin A2 (2.9-fold), cyclin B2 (2.9-fold), cyclin D2 (1.5-fold) and p21 (1.6-fold) in insulinomas at 10 months of age.

\section{Validation of gene expression alteration by quantitative RT-PCR}

In order to confirm the microarray analysis, we analyzed the mRNA expression level of 13 selected genes by real-time quantitative RT-PCR. To this end, we used a total of 6 mRNA samples from Men1 $1^{F / F}$ mice with four at 3-6 months and two at 10 months, 7 and 6 from Menl $\beta$-cell-specific mutant mice at 6 and 10 months respectively, including those used for the microarray. The altered expression of 11 genes out of 13 tested was confirmed by quantitative RT-PCR (see Table 2), as was the reduction of Menl expression in late tumour samples. Moreover, we noticed that Fgf9 and Mapk8ipl expression was up-regulated only in three out of six insulinomas at 10 months (data not shown). Their variable expression in mouse Menl insulinomas may explain why the overexpression of these two genes revealed by microarray analysis has not been validated by quantitative RT-PCR. The validation of the majority of the candidate genes revealed by microarray indicates the quality and the reliability of the microarray analysis performed. We also noticed that, in general, the fold changes of gene expression revealed by quantitative RT-PCR correlate well with that obtained with microarray analysis, except for PthrP. In the latter case, although its overexpression was detected by both methods, the fold change obtained by quantitative RT-PCR is much less than that obtained by microarray analysis. In contrast, an alteration in PthrP expression was found, though weakly, by quantitative RT-PCR in Menl insulinomas at 6 months of age, but was not detected by microarray analysis. The discrepancy may be explained by its very low expression level in the controls (under the background level in microarray analysis), leading to fold change bias and the sample variation in different mice with quantitative PCR analysis at 10 months (data not shown). The data obtained for the genes involved in the IGF pathway, including $I g f 2, \operatorname{Igfbp} 3$, and $\operatorname{Igfbp} 6$, and in cell cycle control pathways, including cyclin A2, cyclin B2, cyclin D2 were shown in Fig. 3. All these genes showed a significantly altered expression by quantitative PCR analysis, except Igfbp3, which nevertheless presented a clear overexpression in three out of six samples tested. Importantly, by quantitative PCR analysis, the increased expression of cyclin A2, cyclin 
A
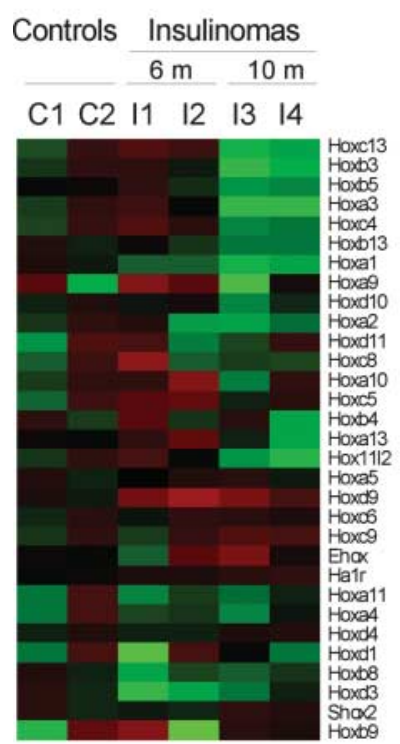

B
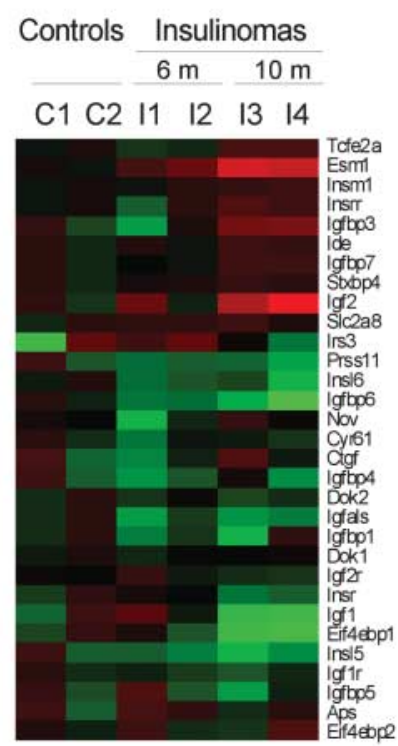

C

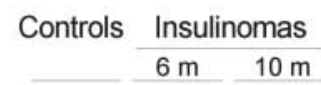

$\begin{array}{lllllll}\mathrm{C} 1 & \mathrm{C} 2 & 11 & 12 & 13 & 14\end{array}$

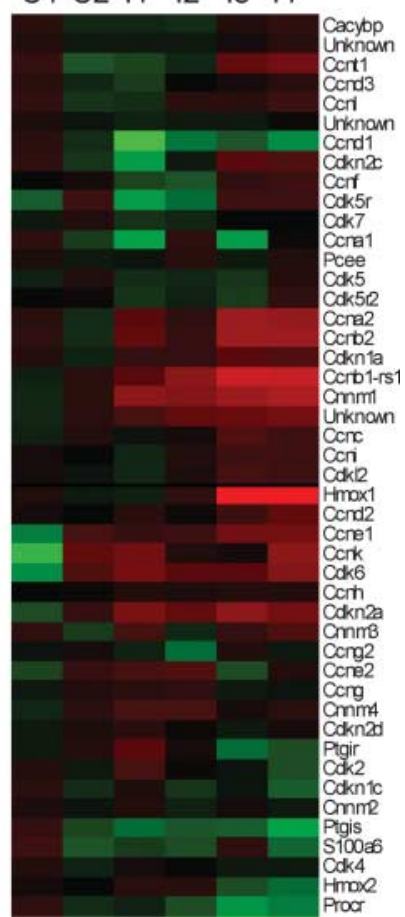

Figure 2 Specific gene cluster analysis of controls islets, 6- and 10-month insulinomas. Each row represents a single gene and each column represents a single control or tumour sample. The results are shown as relative expression level compared to the mean of the controls. Red and green indicate expression levels above and below the mean respectively. A, Hox gene cluster. B, IGF pathway cluster. C, Cell cycle cluster.

$B 2$ and cyclin D2 was detected in Men $1 \beta$-cell-specific mutant mice at 6 months, indicating that their expression change is the early molecular events during the tumour development.

Shortly after our quantitative RT-PCR validation work, Lee et al. has reported effects of the Rip-Cre transgene on glucose metabolism (Lee et al. 2006). To make sure that the gene alteration observed above was not due to the influence of the Rip-Cre ${ }^{+}$transgene, we have checked the expression of several validated genes in the parental Cre-expressing mice strain, including cyclin A2, cyclin $B 2$ and $I G F 2$. The results showed that the expression of all these three genes in the islets from $\mathrm{Rip}^{-\mathrm{Cre}^{+}}$mice was similar to those from $\mathrm{MenI} \mathrm{I}^{\mathrm{F} / \mathrm{F}}$ mice, but differed significantly from mouse Menl insulinomas in a similar way to what found when comparing the islets from Men $1^{F / F}$ mice with those from mouse Menl insulinomas (Supplementary Fig. 1, which may be viewed online at http://erc. endocrinology-journals.org/supplemental/).

\section{IGF2, cyclin A2 and cyclin D2 overexpression detected by immunohistochemical staining in Men1 insulinomas}

We further attempted to investigate the local protein expression of IGF2, cyclin A2 and cyclin D2 in mouse Menl insulinoma. By immunohistochemistry (IHC) analysis, we found that IGF2 was overexpressed in insulinomas from all the tested mice (seven out of seven mice) at around 10 months of age. It is noted that, from the same Men1 mutant mouse, IGF2 overexpression was found only in some of the insulinomas (Fig. 4F) where one insulinoma presented an overt IGF2 expression, but the neighbouring one did not. Also, IGF2 overexpression appeared either diffused (Fig. 4F) or focused (Fig. 4I) in insulinomas, suggesting that it may have both autocrine and paracrine effects. Immunostaining of both cyclin A2 and cyclin D2 in islets from $M e n 1^{F / F}$ mice showed that their expression present a typical cell cycle-dependant pattern, with $20-30 \%$ and $35-40 \%$ of cells showing 
Table 2 Comparison of the qPCR results with the microarray results

\begin{tabular}{|c|c|c|c|c|c|c|c|}
\hline \multirow[b]{3}{*}{ Access No } & \multirow[b]{3}{*}{ Name } & \multicolumn{3}{|c|}{6 months } & \multicolumn{3}{|c|}{10 months } \\
\hline & & \multirow{2}{*}{$\begin{array}{l}\text { Micro-array } \\
\text { Fold change }\end{array}$} & \multicolumn{2}{|c|}{ q PCR } & \multirow{2}{*}{$\begin{array}{l}\text { Micro-array } \\
\text { Fold change }\end{array}$} & \multicolumn{2}{|c|}{ q PCR } \\
\hline & & & Fold change & $P$ value & & Fold change & $P$ value \\
\hline \multicolumn{8}{|l|}{ Up-regulation } \\
\hline AK004995 & Bmp1 & - & - & & $\uparrow 3.3$ & $\uparrow 3.2$ & 0.0022 \\
\hline NM_010514 & IGF2 & - & - & & $\uparrow 4.5$ & $\uparrow 4$ & 0.0022 \\
\hline NM_013518 & Fgf9 & - & $\uparrow 1.2$ & 0.0350 & $\uparrow 3.6$ & - & \\
\hline NM_011162 & Mapk8ip & - & $\uparrow 1.3$ & 0.0221 & $\uparrow 2.7$ & - & \\
\hline NM_008827 & Pgf & - & $\uparrow 1.3$ & 0.0221 & $\uparrow 3.1$ & $\uparrow 2.3$ & 0.0173 \\
\hline NM_008970 & PthrP & - & $\uparrow 1.8$ & 0.0140 & $\uparrow 16.6$ & $\uparrow 2.4$ & 0.0152 \\
\hline NM_009828 & Ccna2 & - & $\uparrow 2.7$ & 0.0047 & $\uparrow 2.9$ & $\uparrow 2.9$ & 0.0087 \\
\hline NM_016707 & Bcl11a & $\uparrow 2.5$ & $\uparrow 2.7$ & 0.0012 & $\uparrow 4.5$ & $\uparrow 3$ & 0.0043 \\
\hline NM_007765 & Crmp1 & $\uparrow 2.8$ & $\uparrow 4.4$ & 0.0012 & $\uparrow 9.9$ & $\uparrow 7.8$ & 0.0022 \\
\hline NM_009829 & Ccnd2 & - & $\uparrow 1.3$ & 0.0051 & - & - & \\
\hline NM_007630 & Ccnb2 & $\uparrow 1.5$ & $\uparrow 3.7$ & 0.0025 & $\uparrow 2.9$ & - & \\
\hline \multicolumn{8}{|l|}{ Down-regulation } \\
\hline NM_019395 & Fbp1 & $\downarrow 8.4$ & - & & $\downarrow 4.6$ & $\downarrow 2.6$ & 0.0411 \\
\hline NM_008344 & IGFbp6 & $\downarrow 1.8$ & - & & $\downarrow 5.1$ & $\downarrow 2.8$ & 0.0411 \\
\hline AF024513 & Men1 & ND & $\downarrow 1.8$ & 0.0023 & ND & $\downarrow 12.6$ & 0.0022 \\
\hline
\end{tabular}

The difference was considered significant when $P$-value was $\leq 0.05$.

strong positive staining for cyclin A2 and cyclin D2 respectively (Fig. 4J, M). On the contrary, the proportion of strong positive cells was markedly increased in mouse Menl insulinomas to more than $70 \%$ on average for cyclin A2 (Fig. 4K and L), and more than $80 \%$ on average for cyclin D2 (Fig. $4 \mathrm{~N}$ and $\mathrm{O})$. The increase of cyclin A2 and cyclin D2-positive cells was observed in most of the mutant mice tested regardless of the age (two out of two, and two out of three for insulinomas at 6 and 10 months of age for cylin A2, and two out of two for insulinomas both at 6 and 10 months of age for cyclin D2). Taken together, the detection of IGF2, cyclin A2 and cyclin D2 overexpression by IHC analysis in mouse Menl insulinomas indicates that their deregulated expression may be among the crucial events participating in the tumorigenesis of $\beta$-cells triggered by menin inactivation.

\section{Core DMR2 of the Igf2 gene is hyper-methylated in mouse Men1 insulinomas}

It is known that the expression of IGF2 is regulated by both genetic and epigenetic mechanisms. We have thus checked the methylation status of regulatory regions of the Igf 2 gene. To this end, DNA methylation patterns on $81 \mathrm{CpGs}$ in the DMR0, DMR1 and DMR2 as well as in other CpG-rich regions situated in exons and introns of the gene were analysed by pyrosequencing. Pyrosequencing has become an increasingly popular technology for the analysis of DNA methylation patterns as it combines important features such as ease-of-use, robustness and quantitative accuracy with high resolution. It is a sequencing-by-synthesis method converting the amount of pyrophosphate released upon nucleotide incorporation into a luminometric signal of proportional intensity. It thereby permits the accurate quantification of multiple $\mathrm{CpGs}$ in a sequence of up to 150 nucleotides without the need for laborious sequencing and cloning. Although all regions exhibited some, but not significant, variability of the methylation level at consecutive CpGs (Fig. 5), only DNA extracted from the insulinomas at 6 and 10 months of age showed a significant hyper-methylation at five $\mathrm{CpGs}$ of the DMR2 when compared with control mice $(P$ values between $P=4.6 \times 10^{-5}$ and $P=0.0002$ for each of the CpGs analysed individually, and $P<1 \times 10^{-10}$ when all $\mathrm{CpGs}$ taken into account). The insulinomas $(N=15)$ had a mean methylation independent of age of $65.6 \pm 7.0 \%$ compared with $51.3 \pm 3.1 \%$ in the control $\left(M e n 1^{F / F}\right)$ mice $(N=6)$. No statistically significant difference in the methylation levels was found between conditional knockout mice at $6(N=8)$ and 10 months $(N=7)$ of age $(66.9 \pm 8.7 \%$ at 10 months vs $64.6 \pm 6.0 \%$ at 6 months of age). This hypermethylation was confined only to the endocrine pancreas, and was not observed in any of the other analysed organs (tail, adrenal, pituitary and exocrine pancreas) in the same mice. Methylation levels were 

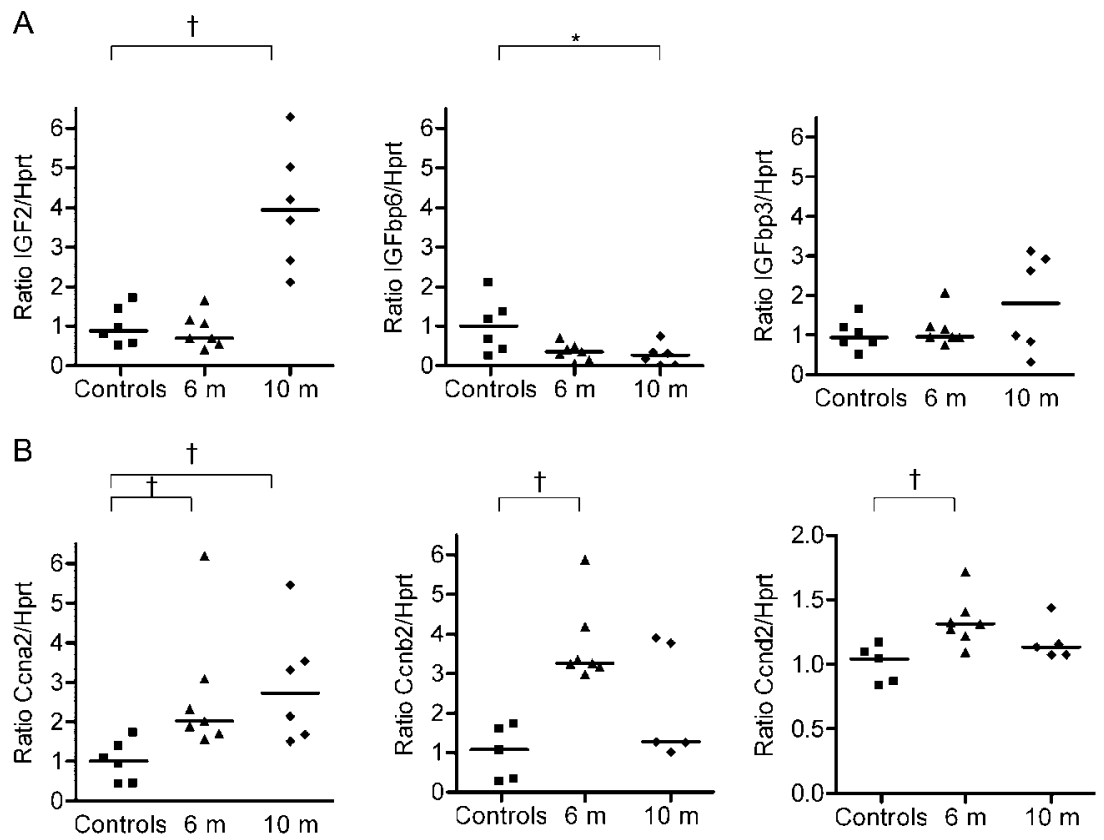

Figure 3 Quantitative PCR analysis of candidate genes of the microarray. mRNA levels of Igf2, Igfbp6, Igfbp3 (A), cyclin A2, cyclin $B 2$ and cyclin D2 (B) were determined from a minimum of five samples of control islets, $6-(6 \mathrm{~m})$ and 10 -month (10m) insulinomas by quantitative PCR. Hprt was used as an internal standard. Bars represent the median. ${ }^{\star} P<0.05 .{ }^{\dagger} P<0.01$.

unchanged in all the five analyzed tissues in the control mice. No difference was found between male and female mice. To ensure that the increase in methylation was not due to the influence of the Rip-Cre ${ }^{+}$mice, the DMR2 was also analyzed in the parental Cre expressing strain. The obtained methylation profile was identical to that of the control mice $(51.0 \pm 3.1 \%$ $\mathrm{Rip}^{-C r e}{ }^{+}(N=3)$ vs $51.3 \pm 3.1 \% \operatorname{Menl}^{F / F}(N=6)$. Four of the hyper-methylated $\mathrm{CpGs}$ are situated in the core DMR2 and coincide with the region previously shown to increase transcription of the growth factor when methylated (Murrell et al. 2001). IGF2 is also regulated by an imprinting control region situated upstream of the $H 19$ gene containing four binding sites for the insulator CTCF protein (CCCTC-binding factor). We therefore additionally analysed the DNA methylation patterns at two of the CTCF sites (CTCF sites 1 and 4), and no significant difference was found between mouse Menl insulinomas and control islets (data not shown).

We have also analyzed the methylation patterns at promoters of the genes involved in cell cycle or proliferation controls and known to be regulated by epigenetic mechanisms, including $p 27, p 18$ and PTHrP genes. However, we failed to reveal any significant change in mouse Menl insulinomas (data not shown).

\section{Discussion}

In the current study, we have characterized the gene expression profile of insulinomas developed in Menl $\beta$-cell mutant mice at early and late stages using microarray analysis. The results showed that the expression of a substantial number of genes is deregulated in tumorigenesis of $\beta$-cells, beginning from the mouse Menl insulinomas at 6 months of age. More importantly, with the combined analyses, our data allowed us to highlight the early involvement of both genetic and epigenetic events taking part in the tumorigenesis of the pancreatic $\beta$-cells triggered by menin inactivation.

Among the previously known islet-related growthpromoting factors, $P$ thr $P$ was found to be significantly overexpressed in mouse Menl insulinomas from both mice at 6 and 10 months of age. Fgf9, previously found upregulated in human MEN1 islet tumours (Dilley et al. 2005), was also overexpressed, though slightly, in mouse Menl insulinomas at 6 months. However, the expression of Myc, known to be involved in $\beta$-cell tumorigenesis (for review see Pelengaris \& Khan 2001), was not altered. Suppression of apoptosis is considered to be an important event in both human and mouse $\beta$-cell tumorigenesis (Pelengaris \& Khan 2001), and it has been reported previously that MEN1 islet 

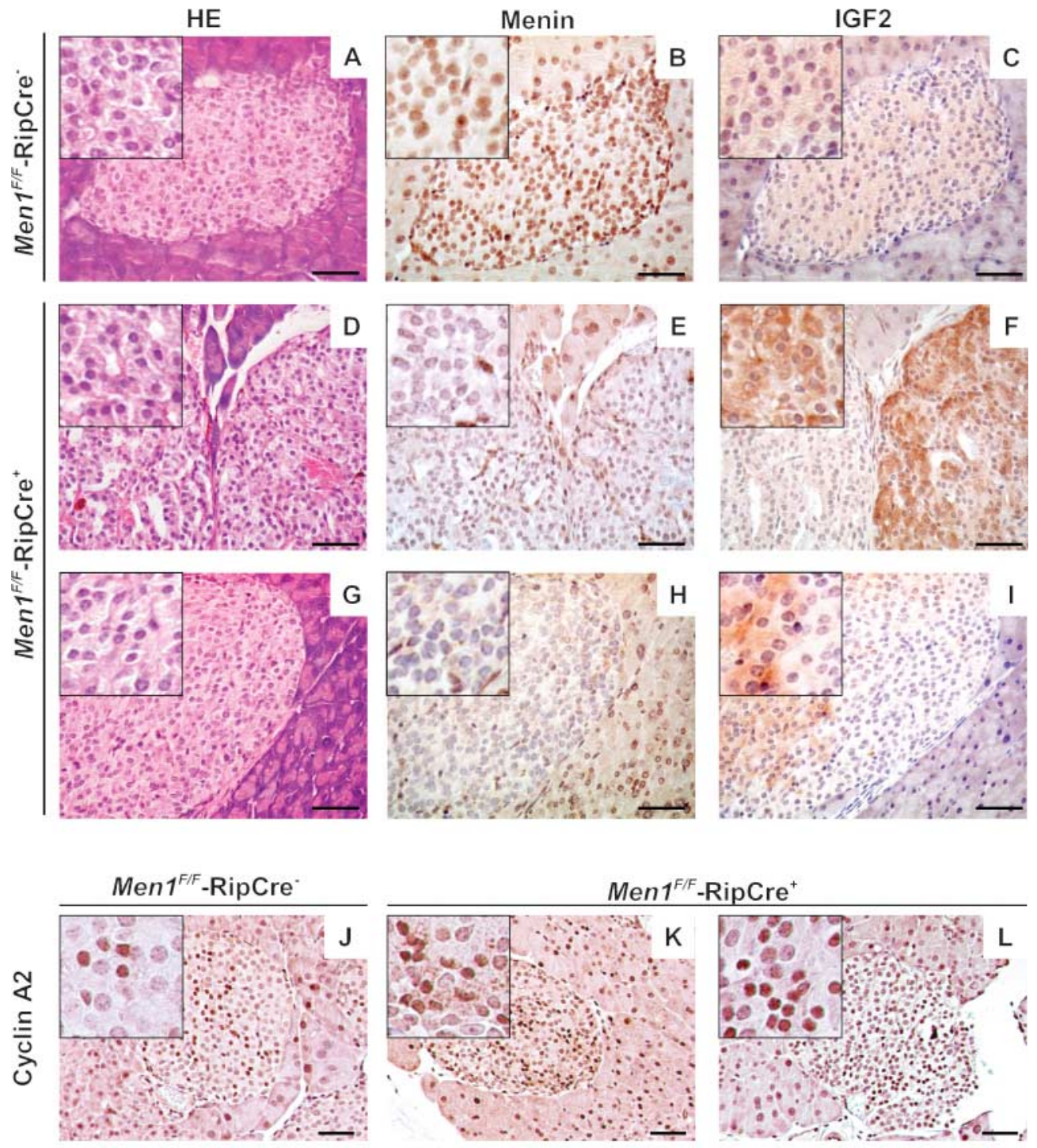

-RipCre ${ }^{+}$
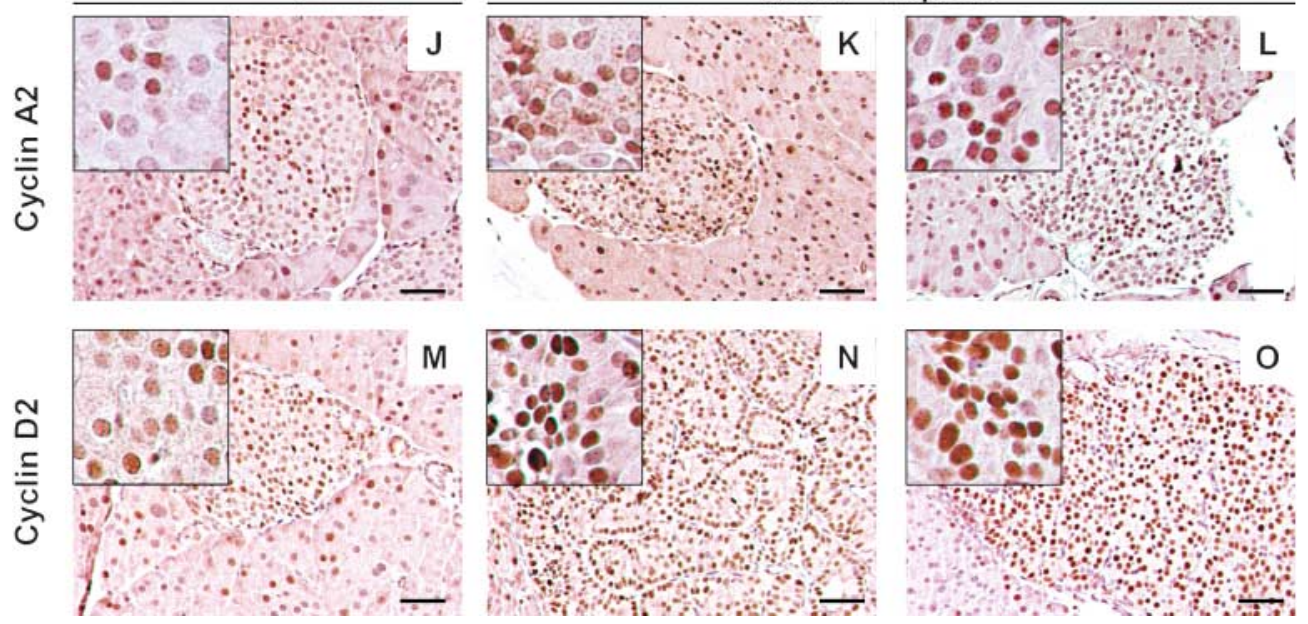

Figure 4 IGF2, cyclin A2 and cyclin D2 proteins in mouse Men1 insulinomas. A, D, G: H\&E staining. B, E, H: Immunostaining of menin. C, F, I: Immunostaining of IGF2. J-L: Immunostaining of cyclin A2. M-O: Immunostaining of D2. A-C, J, M: pancreas from Men1 ${ }^{F / F}$-RipCre ${ }^{-}$mice at 12 months. D-I, L, N: insulinomas from Men1 ${ }^{F / F}$-RipCre ${ }^{+}$mice at 12 months. K, O: insulinomas from $M_{e n 1^{F / F}}{ }^{-R i p C r e}{ }^{+}$mice at 6 months. Inserts show an amplified view of a part of the islet. The scale bars are $50 \mu \mathrm{m}$.

tumours have an altered expression of several apoptosis genes (Dilley et al. 2005). Interestingly, in the current study, the expression of both genes having pro- or anti-apoptotic functions was found to be altered. This may result from the integrated effects of abnormal cell proliferation and cell death induced by certain growth factors. We have also checked the expression of proteins known to interact with menin in our tumour samples, such as JunD, Smad3 and NFKB factors, and none of these factors showed altered 

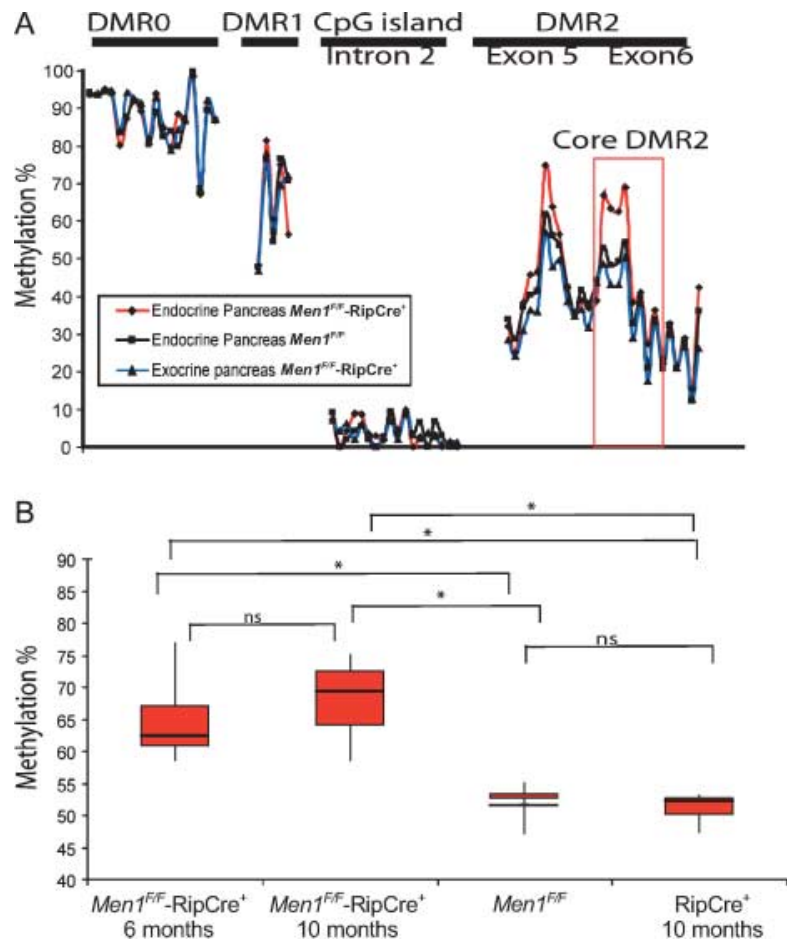

Figure 5 Methylation profile of the different analysed regions in the lgf2 gene. A. The methylation profile obtained for the exocrine pancreas derived from the Men $1^{F / F}-\mathrm{RipCre}^{+}$mice is identical to the profile obtained from the adrenal, pituitary and the tail. The profile shown for the endocrine pancreas of the $M e n 1^{F / F}$ mice is representative for all tissues of the Men $1^{F / F}$ control mice as well as the RipCre ${ }^{+}$mice. Significant methylation differences are confined to $5 \mathrm{CpGs}$ in the DMR2, of which four consecutive ones are in the core DMR2. B. Box-plot diagrams for the methylation differences at these four consecutive CpGs are shown. ${ }^{*} P<0.001$, ns, no statistical significant difference.

transcriptional expression. We have observed an increased expression of secretogranin III starting from 6 months, consistent with a previous report showing the strong expression of protein/insulin secretion pathway in human insulinoma tissue (Wang et al. 2004). Finally, among the genes with altered expression in 6 months insulinomas, we noticed that astrotactin, a membrane protein involved in cell migration, was upregulated both in the early and the late stages of tumour progression, suggesting that the alteration of cell migration may be an important feature of mouse Menl insulinomas.

Our data highlight that the gene expression alteration of cell cycle control genes may play an important role in tumorigenesis of mouse $\beta$-cells related to menin inactivation. Interestingly, whereas cyclin D1, whose overexpression has been reported to occur frequently in human pancreatic endocrine tumours (Chung et al. 2000), did not show significant changes in expression in this model, both microarray and quantitative RT-PCR analyses demonstrated that cyclin A2, B2 and D2 were significantly up-regulated in insulinomas at the early stage. Moreover, the overexpression of cyclin A2 and D2 has been further confirmed by immunostaining analysis, with the results showing that the proportion of the cells expressing these two factors increased in tumour cells. Recently, cyclin D2 has been identified as the major D-type cyclin expressed in $\beta$-cells and essential for $\beta$-cells expansion (Kushner et al. 2005). However, the functional role of cyclin A2 and B2 in islet cells is so far poorly documented. Our data provide the first genetic evidence indicating that regulating the expression of these cyclins may be an important mechanism for menin to control $\beta$-cell proliferation. As little is known so far concerning the regulation of these cyclins in islet cells by menin, it will be interesting for future studies to investigate and study the mechanism of interplay between menin and these cyclins in islet cells. Taken together, the overexpression of cyclin A2, B2 and D2 may suggest that these gene alterations lead to the major early disturbance of cell cycle control in mouse Menl insulinomas.

Our data highlighted the altered expression of the IGF pathway, including the down-regulation of IGF1 and IGFbp6, and the up-regulation of IGF2 and IGFbp3. The down-regulation of Igfl expression detected in our mouse Menl insulinoma model seems to be consistent with the observation that Igfl pancreas-specific disruption led to $\beta$-cell hypertrophy and increased cell survival (Lu et al. 2004). IGFbp3 overexpression has been previously reported in pancreatic endocrine neoplasm and in other cancers, particularly in metastatic pancreatic endocrine neoplasm (Maitra et al. 2003, Hansel et al. 2004). Indeed, we noticed that half of the tested insulinoma samples from Menl mutant mice at 10 months (three out six) presented overt IGFbp3 overexpression, whereas no significant alteration could be observed with samples from mice at 6 months, suggesting that IGFbp3 overexpression is a non-systematic and late event in this model. As for IGF2, its overexpression has been detected by both quantitative RT-PCR and immunostaining analyses in all the mice tested in the current study. IGF2 overexpression has been well-documented in abnormal $\beta$-cells proliferation (Vasavada et al. 2006). Devedjian et al. (2000) have demonstrated that pancreases from transgenic mice overexpressing IGF2 showed an increase in $\beta$-cell mass, disordered organization of islets, hyperinsulinemia, mild hyperglycaemia, and altered glucose and insulin tolerance. 
Furthermore, its expression has been detected in human islet tumours, especially in insulinomas (Hoog et al. 2001), and its overexpression was also observed in a mouse Rip-Tag insulinoma model (Christofori et al. 1994). Therefore, the up-regulation of IGF2 expression seen in this study could be considered as one of the major factors taking part in the tumorigenesis of $\beta$-cells, triggered by menin inactivation.

We have adopted pyrosequencing for evaluating the methylation levels in the regulatory regions of the Igf2 gene, which permits the direct and accurate quantification of the methylation levels at multiple CpGs in a sequence of up to 120 base pairs without the need for time-consuming and laborious cloning and sequencing. Very interestingly, by analysing the methylation status of all the three DMRs of the Igf2 gene, we have found that five $\mathrm{CpG}$ sites of the core DMR2 were all hypermethylated in islets lesions. Methylation of the same four of five $\mathrm{CpG}$ sites has been previously reported to augment $I g f 2$ expression by increasing the level of transcription initiation (Murrell et al. 2001). To our knowledge, this is the first time where the hypermethylation of this regulatory element is documented in tumour tissues. Furthermore, the hyper-methylation of these elements was found in islet lesions from Men1 $\beta$-cell mutant mice at 6 months of age, even before IGF2 overexpression is found at the transcriptional level, suggesting that abnormal methylation of these silencing sites is an early event. Our work thus provided an important clue to the molecular mechanism leading to IGF2 overexpression observed in mouse Menl insulinoma. It will be interesting to investigate whether there is a causal relation between IGF2 overexpression and the observed hyper-methylation at DMR2 region, and whether the same epigenetic alteration happens in human insulinoma or other cancers. Considering menin's role in histone methylation (Hughes et al. 2004, Yokoyama et al. 2004, Milne et al. 2005) and acetylation (Kim et al. 2003) and the interaction between these process and DNA methylation, it would not be surprising that menin may also play a role, directly or indirectly, in DNA methylation.

In this study, we took advantage of the synchronized and homogenous tumour development features of insulinomas derived in Menl $\beta$-cell mutant mice to identify the factors taking part in tumour initiation and progression triggered by menin inactivation. Our data highlight several early genetic and epigenetic events that are of importance in the development of mouse Menl insulinomas, including the overexpression of IGF2 and cyclin A2, B2 and D2. Furthermore, the overexpression of IGF2 is most likely mediated by a hyper-methylation mechanism that is associated with the absence of menin. Further studies of mouse Menl insulinomas may shed light onto the physiological control of $\beta$-cell proliferation and also onto the underlying mechanisms of both metabolic diseases and tumours affecting pancreatic $\beta$-cell.

\section{Acknowledgements}

We thank Dominique Galendo and Marie-Pierre Cros for the maintenance of the mouse colonies (IARC, Lyon, France), Nicole Lyandrat, Christine Carreira (IARC, Lyon, France) and Arnaud de la Fouchardiere (CLB, Lyon, France) for histological assistance. We also thank Catherine Rey (Neurobiotec Services, Lyon, France) for technical advice for RT-qPCR and scientific discussion, Pedro Luis Perrera (Universtity of Geneva, Geneva, Switzerland) for Rip-Cre mice and Joanna I Loizou (IARC, Lyon, France) for the preparation of this manuscript. This study is supported by the Ligue contre le Cancer du Rhône and de la Loire, and the Association pour la Recherche contre le Cancer, France. During this study S F was the recipient of fellowships from Ligue contre le Cancer de la Loire and the Association pour la Recherche contre le Cancer, France.

\section{References}

Agarwal SK, Kester MB, Debelenko LV, Heppner C, Emmert-Buck MR, Skarulis MC, Doppman JL, Kim YS, Lubensky IA, Zhuang Z et al. 1997 Germline mutations of the MEN1 gene in familial multiple endocrine neoplasia type 1 and related states. Human Molecular Genetics 6 1169-1175.

Bassett JH, Forbes SA, Pannett AA, Lloyd SE, Christie PT, Wooding C, Harding B, Besser GM, Edwards CR, Monson JP et al. 1998 Characterization of mutations in patients with multiple endocrine neoplasia type 1 . American Journal of Human Genetics 62 232-244.

Bertolino P, Radovanovic I, Casse H, Aguzzi A, Wang Z \& Zhang C 2003a Genetic ablation of the tumor suppressor menin causes lethality at mid-gestation with defects in multiple organs. Mechanisms of Development 120 549-560.

Bertolino P, Tong W, Galendo D, Wang Z \& Zhang C 2003b Heterozygous Men 1 mutant mice develop a range of endocrine tumors mimicking multiple endocrine neoplasia type 1. Molecular Endocrinology 17 1880-1892.

Bertolino P, Tong W, Herrera PL, Casse H, Zhang CX \& Wang Z 2003c Pancreatic beta-cell-specific ablation of the multiple endocrine neoplasia type 1 (MEN1) gene causes full penetrance of insulinoma development in mice. Cancer Research 63 4836-4841. 
Biondi C, Gartside M, Tonks I, Paterson C, Hayward NK \& Kay GF 2002 Targeting and conditional inactivation of the murine Men 1 locus using the Cre recombinase: loxP system. Genesis 32 150-151.

Biondi CA, Gartside MG, Waring P, Loffler KA, Stark MS, Magnuson MA, Kay GF \& Hayward NK 2004 Conditional inactivation of the MEN1 gene leads to pancreatic and pituitary tumorigenesis but does not affect normal development of these tissues. Molecular and Cellular Biology 24 3125-3131.

Christofori G, Naik P \& Hanahan D 1994 A second signal supplied by insulin-like growth factor II in oncogeneinduced tumorigenesis. Nature 369 414-418.

Chung DC, Brown SB, Graeme-Cook F, Seto M, Warshaw AL, Jensen RT \& Arnold A 2000 Overexpression of cyclin D1 occurs frequently in human pancreatic endocrine tumors. Journal of Clinical Endocrinology and Metabolism 85 4373-4378.

Cozar-Castellano I, Takane KK, Bottino R, Balamurugan AN \& Stewart AF 2004 Induction of beta-cell proliferation and retinoblastoma protein phosphorylation in rat and human islets using adenovirus-mediated transfer of cyclin-dependent kinase-4 and cyclin D1. Diabetes 53 149-159.

Crabtree JS, Scacheri PC, Ward JM, Garrett-Beal L, EmmertBuck MR, Edgemon KA, Lorang D, Libutti SK, Chandrasekharappa SC, Marx SJ et al. 2001 A mouse model of multiple endocrine neoplasia, type 1, develops multiple endocrine tumors. PNAS 98 1118-1123.

Crabtree JS, Scacheri PC, Ward JM, McNally SR, Swain GP, Montagna C, Hager JH, Hanahan D, Edlund H, Magnuson MA et al. 2003 Of mice and MEN1: Insulinomas in a conditional mouse knockout. Molecular and Cellular Biology 23 6075-6085.

Devedjian JC, George M, Casellas A, Pujol A, Visa J, Pelegrin M, Gros L \& Bosch F 2000 Transgenic mice overexpressing insulin-like growth factor-II in beta cells develop type 2 diabetes. Journal of Clinical Investigation 105 731-740.

Dilley WG, Kalyanaraman S, Verma S, Cobb JP, Laramie JM \& Lairmore TC 2005 Global gene expression in neuroendocrine tumors from patients with the MEN1 syndrome. Molecular Cancer 49.

Dupont J, Tost J, Jammes H \& Gut IG 2004 De novo quantitative bisulfite sequencing using the pyrosequencing technology. Analytical Biochemistry 333 119-127.

Farnebo F, Teh BT, Kytola S, Svensson A, Phelan C, Sandelin K, Thompson NW, Hoog A, Weber G, Farnebo LO et al. 1998 Alterations of the MEN1 gene in sporadic parathyroid tumors. Journal of Clinical Endocrinology and Metabolism 83 2627-2630.

Giraud S, Zhang CX, Serova-Sinilnikova O, Wautot V, Salandre J, Buisson N, Waterlot C, Bauters C, Porchet N, Aubert JP et al. 1998 Germ-line mutation analysis in patients with multiple endocrine neoplasia type 1 and related disorders. American Journal of Human Genetics 63 455-467.
Hansel DE, Rahman A, House M, Ashfaq R, Berg K, Yeo CJ \& Maitra A 2004 Met proto-oncogene and insulin-like growth factor binding protein 3 overexpression correlates with metastatic ability in welldifferentiated pancreatic endocrine neoplasms. Clinical Cancer Research 10 6152-6158.

Hoog A, Kjellman M, Nordqvist AC, Hoog CM, Juhlin C, Falkmer S, Schalling M \& Grimelius L 2001 Insulin-like growth factor-II in endocrine pancreatic tumours. Immunohistochemical, biochemical and in situ hybridization findings. Acta Pathologica, Microbiologica, et Immunologica Scandinavica 109 127-140.

Hughes CM, Rozenblatt-Rosen O, Milne TA, Copeland TD, Levine SS, Lee JC, Hayes DN, Shanmugam KS, Bhattacharjee A, Biondi CA et al. 2004 Menin associates with a trithorax family histone methyltransferase complex and with the hoxc8 locus. Molecular Cell 13 587-597.

Kim H, Lee J, Cho E, Liu JO \& Youn H 2003 Menin, a tumor suppressor, represses JunD-mediated transcriptional activity by association with an $\mathrm{mSin} 3 \mathrm{~A}$-histone deacetylase complex. Cancer Research 63 6135-6139.

Kushner JA, Ciemerych MA, Sicinska E, Wartschow LM, Teta M, Long SY, Sicinski P \& White MF 2005 Cyclins D2 and D1 are essential for postnatal pancreatic beta-cell growth. Molecular and Cellular Biology 25 3752-3762.

Larsson C, Skogseid B, Oberg K, Nakamura Y \& Nordenskjold M 1988 Multiple endocrine neoplasia type 1 gene maps to chromosome 11 and is lost in insulinoma. Nature 332 85-87.

Lee JY, Ristow M, Lin X, White MF, Magnuson MA \& Hennighausen L 2006 RIP-Cre revisited, evidence for impairments of pancreatic beta-cell function. Journal of Biological Chemistry 281 2649-2653.

Libutti SK, Crabtree JS, Lorang D, Burns AL, Mazzanti C, Hewitt SM, O'Connor S, Ward JM, Emmert-Buck MR, Remaley A et al. 2003 Parathyroid gland-specific deletion of the mouse Men1 gene results in parathyroid neoplasia and hypercalcemic hyperparathyroidism. Cancer Research 63 8022-8028.

Lu Y, Herrera PL, Guo Y, Sun D, Tang Z, LeRoith D \& Liu J 2004 Pancreatic-specific inactivation of IGF-I gene causes enlarged pancreatic islets and significant resistance to diabetes. Diabetes 53 3131-3141.

Maitra A, Hansel DE, Argani P, Ashfaq R, Rahman A, Naji A, Deng S, Geradts J, Hawthorne L, House MG et al. 2003 Global expression analysis of well-differentiated pancreatic endocrine neoplasms using oligonucleotide microarrays. Clinical Cancer Research 9 5988-5995.

Marzo N, Mora C, Fabregat ME, Martin J, Usac EF, Franco C, Barbacid M \& Gomis R 2004 Pancreatic islets from cyclin-dependent kinase 4/R24C (Cdk4) knockin mice have significantly increased beta cell mass and are physiologically functional, indicating that $\mathrm{Cdk} 4$ is a potential target for pancreatic beta cell mass regeneration in Type 1 diabetes. Diabetologia 47 686-694. 
Milne TA, Hughes CM, Lloyd R, Yang Z, Rozenblatt-Rosen O, Dou Y, Schnepp RW, Krankel C, Livolsi VA, Gibbs D et al. 2005 Menin and MLL cooperatively regulate expression of cyclin-dependent kinase inhibitors. PNAS 102 749-754.

Murrell A, Heeson S, Bowden L, Constancia M, Dean W, Kelsey G \& Reik W 2001 An intragenic methylated region in the imprinted Igf 2 gene augments transcription. EMBO Reports 2 1101-1106.

Pelengaris S \& Khan M 2001 Oncogenic co-operation in betacell tumorigenesis. Endocrine-Related Cancer 8 307-314.

Rane SG, Dubus P, Mettus RV, Galbreath EJ, Boden G, Reddy EP \& Barbacid M 1999 Loss of Cdk4 expression causes insulin-deficient diabetes and Cdk4 activation results in beta-islet cell hyperplasia. Nature Genetics 22 44-52.

Thakker RV 1995 Multiple endocrine neoplasia type 1. In Endocrinology, pp 2815-2831. Eds LJ De Groot, G Besser, J Jameson, D Loriaux, J Marshall, W Odell, J Potts \& A Rubersteinp. Philadelphia: Saunders Press.

Tost J, El abdalaoui H \& Gut IG 2006 Serial pyrosequencing for quantitative DNA methylation analysis. BioTechniques 40 721-726.

Uchida T, Nakamura T, Hashimoto N, Matsuda T, Kotani K, Sakaue H, Kido Y, Hayashi Y, Nakayama KI, White MF et al. 2005 Deletion of Cdkn1b ameliorates hyperglycemia by maintaining compensatory hyperinsulinemia in diabetic mice. Nature Medicine 11 175-182.
Vasavada RC, Gonzalez-Pertusa JA, Fujinaka Y, FiaschiTaesch N, Cozar-Castellano I \& Garcia-Ocana A 2006 Growth factors and beta cell replication. International Journal of Biochemistry \& Cell Biology 38 931-950.

Wang X, Xu S, Wu X, Song H, Mao Y, Fan H, Yu F, Mou B, Gu Y, Xu L et al. 2004 Gene expression profiling in human insulinoma tissue: genes involved in the insulin secretion pathway and cloning of novel full-length cDNAs. Endocrine-Related Cancer 11 295-303.

Wautot V, Vercherat C, Lespinasse J, Chambe B, Lenoir GM, Zhang CX, Porchet N, Cordier M, Beroud C \& Calender A 2002 Germline mutation profile of MEN1 in multiple endocrine neoplasia type 1: search for correlation between phenotype and the functional domains of the MEN1 protein. Human Mutation 20 35-47.

Yokoyama A, Wang Z, Wysocka J, Sanyal M, Aufiero DJ, Kitabayashi I, Herr W \& Cleary ML 2004 Leukemia proto-oncoprotein MLL forms a SET1-like histone methyltransferase complex with menin to regulate Hox gene expression. Molecular and Cellular Biology 24 5639-5649.

Zhuang Z, Vortmeyer AO, Pack S, Huang S, Pham TA, Wang C, Park WS, Agarwal SK, Debelenko LV, Kester M et al. 1997 Somatic mutations of the MEN1 tumor suppressor gene in sporadic gastrinomas and insulinomas. Cancer Research 57 4682-4686. 